Article

\title{
Recovering Industrial Heritage: Restoration of the Wine Cellar Cooperative in Falset (Catalonia, Spain)
}

\author{
Eva Cuerva ${ }^{1,2, *}$, Judith Urbano ${ }^{3}(1)$ and Còssima Cornadó ${ }^{4}(\mathbb{D}$ \\ 1 Group of Construction Research and Innovation (GRIC), Universitat Politècnica de Catalunya, \\ 08032 Terrassa, Spain \\ 2 JG Chair for the Study of Sustainability in Buildings, Universitat Politècnica de Catalunya BarcelonaTECH, \\ 08028 Barcelona, Spain \\ 3 GRHAD—-Research Group in History, Architecture and Design (GRHAD), Universitat Internacional de \\ Catalunya, 08017 Barcelona, Spain; jurbano@uic.es \\ 4 REARQ Research Group, Universitat Politècnica de Catalunya BarcelonaTECH, 08028 Barcelona, Spain; \\ cossima.cornado@upc.edu \\ * Correspondence: eva.cuerva@upc.edu
}

Received: 13 November 2019; Accepted: 9 December 2019; Published: 11 December 2019

\begin{abstract}
Awareness regarding conservation of industrial heritage is recent. Several policies have been adopted to start protecting these buildings because of their historic, artistic and scientific values. Wine cellars are an important example of industrial heritage in Catalonia due to the tradition of this product in the territory and the influence of Art Nouveau and Catalan 'Noucentisme' in their construction and style. The wine cellar in Falset, built by Cèsar Martinell in 1919, has recently been restored and still maintains its original function. This article analyses its history, its architectonic and construction characteristics, as well as the restoration process carried out in 2009, which consisted of recovering its original appearance and allowed to emphasize the architectural value of the building. This restoration is a prototypical example whose experience can be applied in other cases of restoration of wine cellars both for the characteristics of the building and for its good restoration practices. This restoration enabled the wine cellar to continue carrying out its original industrial function, providing suitable conditions to add a new cultural use as well.
\end{abstract}

Keywords: industrial heritage; Catalan cooperatives; wine cellars; architectural restoration; Cèsar Martinell; Art Nouveau; Noucentisme

\section{Introduction}

There is an important problem today with respect to how to preserve architectural heritage and how society can benefit from it. The character of historic buildings can play a significant part in the culture of a society, as it includes aspects of its history. Preservation of such heritage is crucial for societies as it is related to their identity.

There is a need to provide new uses for these buildings to keep them alive for future generations, given the fact that it is usually difficult for them to maintain their original function. Looking for new uses when the original function is obsolete is called adaptive re-use. Conservation of historical buildings needs to take into consideration how they can be preserved by adapting to the new social and economic demands without losing their historical and cultural values. Given this background, adaptive reuse has been one of the best options since it allows to preserve buildings and continue their use in a cost-effective way [1].

However, it is also possible to maintain the original use of a building, as in the example studied in this paper, which was founded as a wine cellar and is still used for the same function today. Restoration 
of architectural heritage can thus take on different forms, which go from minor redesigns to major reconstruction. In some cases, even if the buildings are in good condition, all or part of the facilities may be outdated, this case could lead to a conditioning process. In general, this type of conservation of historical heritage requires a balance between the new requirements and the preservation of its main values.

Regarding industrial heritage sites—whether or not new uses have been provided-any work carried out on an industrial asset must protect the site's intrinsic industrial values or aspects of interest. The new use given to heritage sites, which has served to promote their conservation, should not influence how the public experiences them. The conservation of industrial heritage is frequent in urban regeneration projects, where the improvement of these areas is sought from an aesthetic, functional and economic point of view without losing sight of their historical value [2].

The main objective of this paper is to contribute to the expansion of knowledge of Catalonia's industrial and cultural heritage, and in particular of historical wine cellar cooperatives. In order to spread this knowledge, the architectural restoration of the wine cellar cooperative in Falset is used as a case study. This wine cellar is especially relevant, as it has maintained its original industrial function, adding a new cultural use (tourism and oenology).

\subsection{Cultural Valorisation of Industrial Heritage}

There are many definitions of Industrial Heritage. According to the International Committee for the Conservation of the Industrial Heritage (TICCIH), it refers "to the remains of industrial culture that possess historical, technological, social, architectural and scientific value". Industrial heritage is an economic resource and can become an object of acceptable use in the development of cultural industries, from values as past, identity, authenticity, and scientific and technological knowledge to the involvement and participation of citizens in their management [3,4].

Despite its importance, it is probably one of the least known forms of heritage, and it is a relatively new area. This is mainly because its value is not artistic, but rather a witness of an industrial process important for the society [5]. In addition, there is no general agreement on the recognition of industrial spaces as heritage sites, as many of them are under pressure of demolition and redevelopment [2]. According to Claver and Sebastián [6], Spanish industrial heritage has been historically threatened because it has often been associated with degraded and contaminated areas, unlike other types of heritage that could be romantically associated with art or history.

This is a problem because the industrial remains have been increasing; currently, there are many examples of industrial heritage threatened with disappearance or have almost disappeared. There is a great danger of loss when, in addition to the threatened architecture, there are other elements such as old machinery that have been a testimony of specific forms of manufacturing [7]. The degraded situation of many industrial heritage buildings means that their valuation approach should be oriented not towards conservation but towards rehabilitation, renovation and reconstruction. On the contrary, the preferred theory in traditional preventive conservation deals with the idea of recognizing, valorizing and respecting heritage, focusing on damage preservation [8,9] and maintenance.

Despite this worrying situation, there is a growing literature on the development of industrial heritage from architectural perspectives and urban planning. For example, Stratton [10], when describing successful models of regeneration in industrial heritage, praises the use of general conservation principles applied to existing resources: buildings, landscapes and users. Other authors [11] support the reinvention of cities and their urban regeneration in the current context of globalization. This includes industrial heritage with a revaluation of its cultural aspects. In these projects, the prevailing approach consists of the perspective of tourism that can replace former industrial uses.

As it was mentioned in the introduction, the most popular strategies for the valorization of industrial heritage used to be the conservation of the building maintaining its original use or, more commonly, the adaptive re-use of the industrial asset. However, the conservation of industrial 
heritage requires a change of vision from obsolete industrial spaces to heritage sites which have to be economically and culturally viable [2]. In other words, to place industrial heritage at the same level as another type of heritage more commonly assumed by society and using it as an incentive for the regeneration of certain urban areas. Obviously, the new use has to contribute to the local economy without endangering the heritage site or building [12].

New functions for industrial buildings should promote future sustainability by reinforcing and preserving heritage values. As Cercleux, Merciu and Merciu explain [11], in cities with an important industrial past, the reuse of this heritage becomes an important asset. Changes of usage in industrial buildings to equipment or housing are common in these cases where it is important to preserve the inherited architecture as an identity value of the community.

The item of maintenance and conservation within the Nizhny Tagil Charter of the International Committee for the Conservation of Industrial Heritage (TICCIH) states that industrial heritage can play an important role in the economic regeneration of degraded areas since it offers adaptive reuse opportunities [3]. This practice can contribute to the improvement of the image of areas in decline, especially if it is achieved through community participation in conservation.

Another way to promote industrial heritage is to develop industrial heritage tourism through tourism activities in spaces and buildings that are a testimony of previous industrial periods and processes [13]. Therefore, according to Xie [14], this practice can offer an opportunity for regional restructuring and economic development, tourism can also mean a change of function in the territory towards a more positive vision [11].

Nonetheless, no matter which new use the industrial building has been given after the restoration, every industrial building or site has its own identity, which must be conserved in the intervention or restoration performed. One of the major criticisms in the heritage interventions of recent years is probably that the rehabilitated buildings have been emptied of their original content by restoration projects, causing the lack of references and a memory loss of work and the actual work cultures. As Álvarez [4] said, this leads to the thought that not all restored historic building can accommodate any new functionality.

Valorization of Industrial and Technical Heritage: The Case of Spain and Catalonia

Cultural policy has to deal with industrial heritage, keeping a balance between achieving cultural valorization and economic viability of obsolete spaces. There are many organizations that work on the recovery and recovery of industrial heritage, such as the aforementioned TICCIH, the branches of UNESCO that study different types of heritage or as SHOT (Society for the History of Technology), focused on the history of the technology [7].

The current situation in Spain, according to some authors [6], shows that, as it was mentioned earlier, industrial heritage is considered to be less important than other heritage sectors. One of the problems that cause this situation is the lack of a clear methodology and criteria for the valorization of industrial heritage in Spain.

However, there are certain laws and regulations in Spain that have been promoted to protect and restore architectural heritage, including industrial heritage. For example, the Spanish General Historical Heritage Act 16/85 (Ley General 16/85 del Patrimonio Histórico de España) on Spanish Historical Heritage declares several sites and landscapes to be cultural interest assets. Thanks to this law, mining areas, mills, factories, and quarries have been protected in some parts of the country. On the other hand, the National Plan for Industrial Heritage in Spain (2001) is the main tool to lay the foundations of protection, conservation and reclamation for the future of the historic legacy preserved in the country as a result of industrialization.

The creation of museums and interpretation centers within the context of industrial spaces and buildings has also become increasingly important in Spain. The Management System of Industrial Heritage of Catalonia, the epicenter of which is the Science and Technology Museum of Catalonia located at Vapor Aymerich in Terrassa (Barcelona), an Art Nouveau textile factory designed in 1909 
by the architect Lluis Muncunill, plays an important role in this field. The museum, created in 1983, aims to ensure the conservation, study and dissemination of the industrial heritage of Catalonia. This system can be considered the most elaborated policy for the management of industrial heritage throughout Spanish territory. The museum participates in industrial tourism programs organized by the Network of Municipalities (XATIC, Xarxa de Turisme Industrial de Catalunya) and the provincial council of Barcelona.

The recovery and transformation of this heritage into museums and tourist resources have revalued those industrial spaces, turning them into tangible evidence of the life and culture of the working society, which gave rise to our way of life. The sector of Catalan industrial and technical heritage deems it necessary to provide further tools to promote the study, dissemination and preservation of the heritage of the industrial era, which is in constant transformation. Based on this premise, the Bonaplata awards were created with the aim of rewarding individuals and institutions that have taken steps to assess the industrial heritage of Catalonia through the study, restoration, dissemination or claim of industrial areas, or industrial, technical or scientific buildings and facilities.

The practical case presented in this paper was elected as finalist in the Bonaplata awards of 2013, in the category of restoration of industrial heritage.

\subsection{Industrial Buildings in Catalonia}

In Catalonia, there is a great variety of industrial architecture, including factories, flourmills, distilleries, tanks, wineries, and caves (Catalan cellars). All of these buildings were the result of industrialization and the adoption of economic liberalism in Catalonia in the 19th and early 20th centuries.

Many of those buildings have disappeared, but others, such as winery cooperatives, have been conserved, some of them restored and some adapted to new uses. In the case of the wineries of Nulles and Falset, not only have they been restored, but they are also the only ones still used for the same function they were created for.

Some significant examples of industrial buildings built in that period in Catalonia are the Casarramona factory (Josep Puig i Cadafalch, 1909-1912), an Art Noveau textile factory constructed entirely in brickwork, the traditional Catalan construction system; the Vapor Aymerich (Lluís Muncunill, 1907-1908), a wool textile factory; and the Asland Factory (Rafael Guastavino, 1901-1904), which was the first industrial cement factory in Catalonia.

\subsubsection{Wine Cellar Cooperatives in Catalonia}

Wine industry plays an important role in the Mediterranean countries. It is a fancy industry that is deeply rooted in societies, in their habits and traditions. Wine industry has remained until today, adapting and being a key industry for economic development in those areas. At present, the heritage elements related to the production of wine are protected, especially buildings, with the will to strengthen the cultural identity of these areas that are proud of their ancient industry [15].

The Catalan region of Priorat and Conca de Barberà is known for its expertise in wine production. During the first years of the 20th century, a characteristic type of wine cellar, known as the "Wine Cathedrals", appeared. The architectural features of these buildings, based on the principles of Art Nouveau, turn them into one of the leading exponents of the industrial heritage of Catalonia (Figure 1).

At the end of the 19th century, the great expansion of Catalan agriculture abruptly came to an end because of grape phylloxera, which had previously damaged French grapes, consequently increasing the sales in Catalonia. In the 1880s, the plague crossed the Pyrenees, from the Alt Empordà region in the north to Amposta in the south, seriously affecting the production in Catalonia. Some vineyards were replanted with American grapevines, while others changed crops to cereals, olive trees, carob trees, etc. However, the situation in the Catalan fields became worse due to the loss of the French market and the falling prices. 
In countries like France, the UK, Italy, Belgium or Germany, cooperative movements and associations had already been developed [16]. In Spain, the Law of Associations of 1887 promoted the creation of organizations of a different kind, for example, farmers' societies. However, it was necessary to wait until the Law of Unions in 1906 for agricultural cooperatives to come into existence.

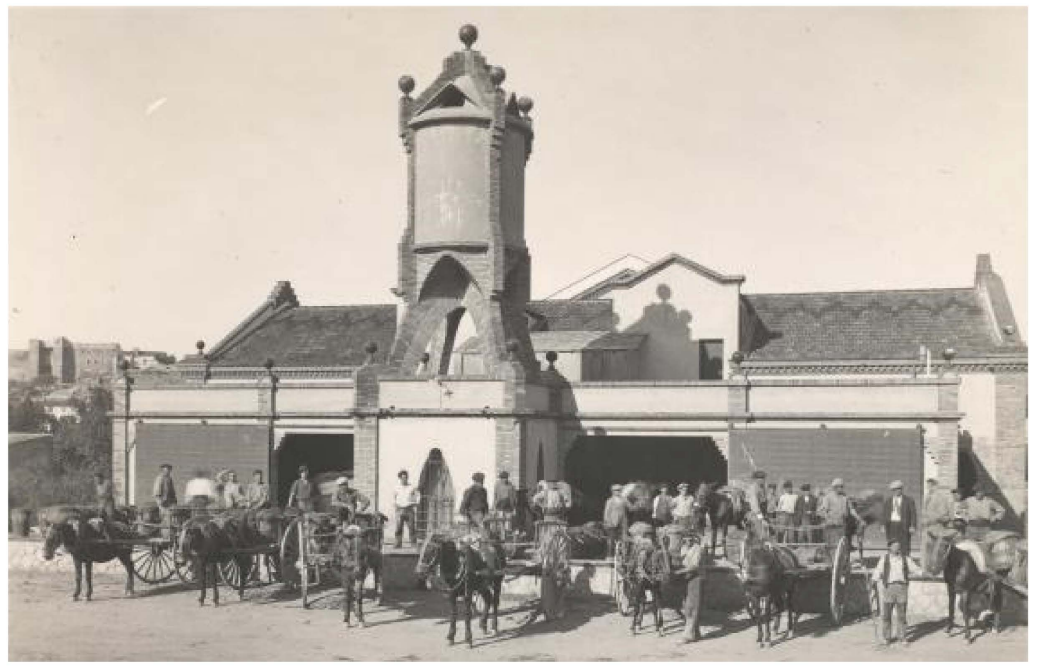

Figure 1. Old picture of the cooperative wine cellar in Falset.

According to Mayayo [17], this phenomenon in the wine sector encompassed two ways: the revolutionary road, which came first and originated in farmers' resistance associations, and the reformist one, in the hands of the progressive bourgeoisie. In both cases, the cellar was the maximum architectonical exponent of these entities. Fuguet [18] highlights the differences in each case: The cellars that were built under the orders of resistance societies were austere, simple and practical buildings, devoid of great decorations. The cellars of the associations of owners were commissioned to architects, and many ornamental motifs and relevant architectonical elements were added to functionality. It is significant that the first ones were called "the cellars of the poor" and the others "the cellars of the rich". The fact that they were called the "wine cathedrals" also gives an idea of the magnitude of some of these constructions.

In spite of these differences, two natural disasters-the mildiu plague caused by fungi, and the hailstorm in 1915-made a lot of owners join the cooperative movement, giving rise to a system of collaboration between social classes, in which owners and workers worked together for a common objective: the modernization of wine production. The role of the Mancomunitat de Catalunya, which was a Catalan institution formed by the four Catalan provincial councils which lasted from 1914 to 1923, was also very important because it promoted the agriculture development of the country by giving loans to peasants and organizing technical support offering advice in matters of technology and production.

Between 1911 and 1916, the architects Claudi Duran i Ventosa and Pere Domènech i Roura built several cellars. From 1918, another architect, Cèsar Martinell, started to build the wine cellar of Rocafort de Queralt. This was the first of almost 50 cellars that Martinell built during his life. It was his most important activity and the one he would become famous for.

In Catalonia, in the early 20th century, a new artistic movement arose: a group of young intellectuals, the "Noucentistas", took over. They were followers of the Art Nouveau ideology in terms of its nationalist attitude and willingness to modernize the country. They diverged, however, in their manner and background: the Noucentista aesthetic took classical art as its reference, breaking away from the Art Nouveau 'romantic chaos', its influence to be found in nature and in the Middle Ages. Moreover, the movement had a collective spirit from its very beginnings, uniting art, politics and institutions on the same path. Reason, rationality and progress were the engines that drove Noucentisme, 
and architecture was one of its most outstanding disciplines. With tendencies that range from the extension of Art Nouveau to the recovery of classical forms and popular architecture, the Noucentistes promoted functional architecture, not only including aesthetic but also social values.

Some of the best examples of this movement are the winery cooperatives which were built in Catalonia during the first two decades of the 20th century. The architecture of these wineries responded to the need to modernize wine production and adapt to a new, much more competitive context full of changes.

The layout of these wineries consisted in large spaces located with rigorous order, which incorporated all the machinery necessary for the industrial production of wine distributed in an area that constituted a large 'assembly line'. They were efficient and rational utilitarian buildings that were designed bearing in mind the process of wine production. This rationality was reflected in the division of workspaces, which was formally established in three areas intended for wine production: the area where grapes were unloaded, the wine-production hall (including the engine room) and the halls of vats or winepresses.

The winery builders recovered and reinterpreted some traditional elements, such as the basilica plan. The structure of parallel areas (usually three, the central one being the widest) was often repeated, confirming that this type of plan has been the most successful layout in the history of universal architecture, as it enables optimum use of space.

It was important to efficiently connect the different spaces of the building, in order to have the grapes quickly conducted to the pressing area and later to the vats and fermentation tanks. In order to make this route easier, two-story cellars were designed, the top floor for the unloading bay of the grapes and the lower floor for the wine-production hall.

The wine vats were built aligned, separated by empty spaces in order to prevent temperature transmission between them (caused by the fermentation process of the grapes). Said empty spaces were ventilated by means of ceramic tubes which facilitated airflow. Small openings, protected by grilles, were also made at ground level to release the carbonic acid, which is denser than air, generated during the fermentation of the must.

Regarding the constructive aspects of winery cooperatives, the ways of covering this great space were also inspired by traditional architecture. For example, Pere Domènech i Roura, responsible for the winery of L'Espluga de Francolí, used pointed diaphragm arches to support the roof of the building, a system that had its origins in the Civil Catalan Gothic. This Gothic system in cellars, however, was soon replaced by parabolic arches (Figure 2), which were often used by Antoni Gaudí.

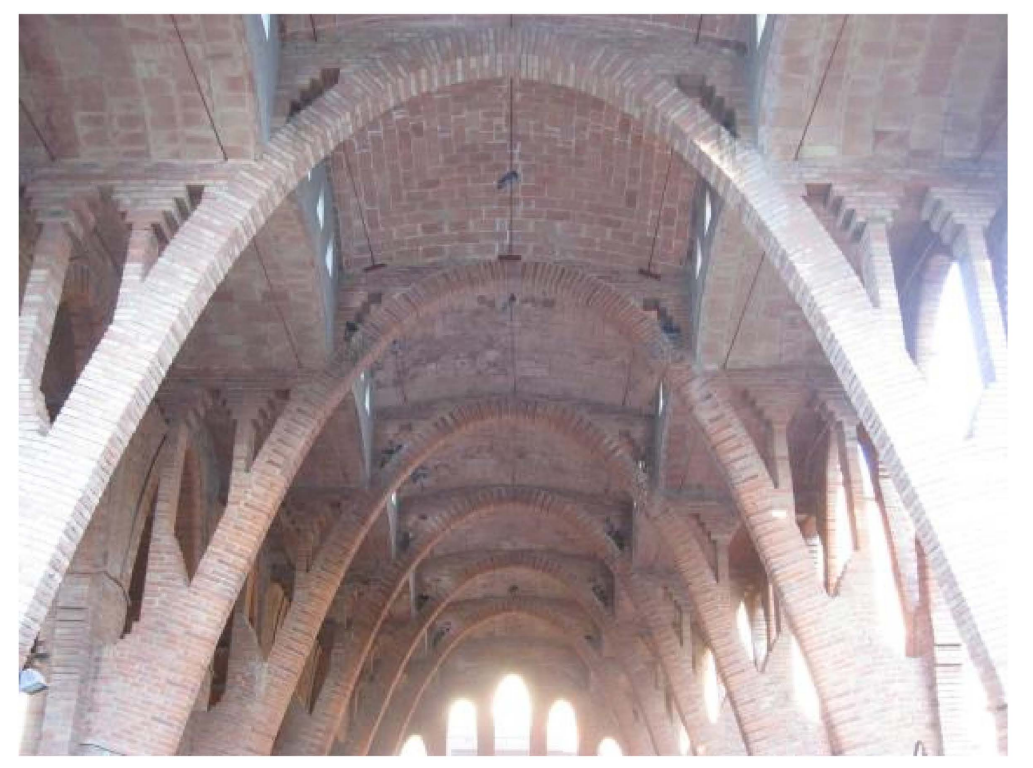

Figure 2. Parabolic arches used as a structure in the cellar of Sant Cugat by Cèsar Martinell, 1921. 
The most important structural feature of the parabolic arches, and what sets them apart from other structural forms, is that the direction of the stress follows the line of the arch for uniformly applied loads. Their shape makes for optimum use of the material, and they are only subject to compression, without needing anchors or buttresses to ensure that the inclined load is transferred to the foundations. The construction of brick parabolic arches, the ones used in modernist wine cellars, was a highly optimized system because they used local materials, that were cheap and readily available, required little transport and used a traditional and well-known construction technique.

Before Gaudí, who saw the structural advantages of parabolic arches, they were used by engineers, mainly in bridges, train stations and markets. Cèsar Martinell, who admired and worked with Gaudí, providing us with one of the best books for understanding Gaudi's life and works [19], introduced parabolic arches in agricultural buildings. Parabolic arches thus became a hallmark of Martinell's wineries.

Although the initial reasons for the use of parabolic arches in agricultural buildings were financial and functional (the increase in the price of wood because of the First World War, its greater resistance and better durability), their aesthetic value should not be forgotten either. The inner space of the building, which was bright and not divided into other rooms, was ruled by the succession of parabolic arches. The roof covering became of secondary importance, and the limit of the height of the space was configured by arches instead of a continuous plane of the roof or ceiling. In most cases, the building consisted of a main nave and two lateral ones, so that the space inside was much larger.

The Catalan vault or flat brick vault (volta catalana, or volta de maó de pla) (Figure 3) is another contribution of traditional architecture; it dates back to ancient Rome, but in Catalonia it was one of the most frequently used constructive elements in farmhouses and popular urban constructions. In this case, bricks are placed on their wide side forming a surface that covers the ceiling. Vaulted ceilings provide the building with great homogeneity, both visually and structurally, as they consist of a single material, which means thermal expansion and contraction is uniform and cracking is avoided. Furthermore, the tiled dry roof makes easier the ventilation of the spaces where wine is made or stored. As far as construction is concerned, this system optimizes the efficiency of the material because structurally it takes advantage of the entire cross section. Catalan vaults were not only used on the roofs of wine cellars, but also in the construction of underground water or wine tanks, in the construction of retaining walls to restrain soil or in the construction of separated vat bases on anchored arches.

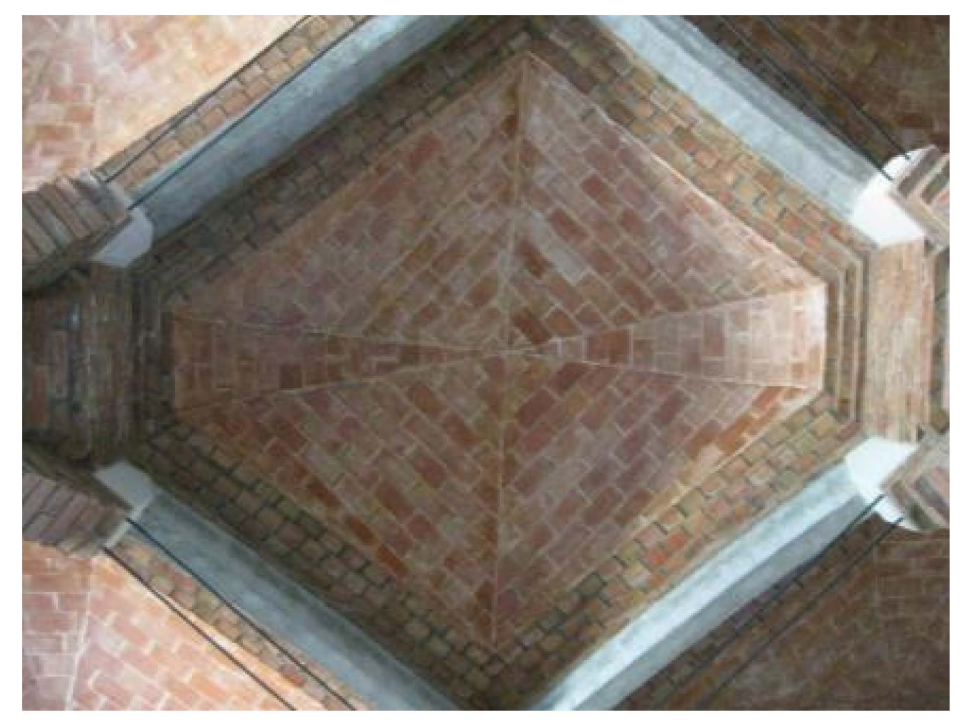

Figure 3. Catalan vault in the interior of the Gandesa cellar by Cèsar Martinell, 1919.

Wood roof trusses (recovered by architects such as Lluís Muncunill in vernacular architecture) (Figure 4) were also widely used in cooperative wine cellars. Roof trusses are building systems 
that consist of a triangular framework-comprising a series of wood or metal beams properly put together-used to bear the weight of pitched roof tiles. They are characterized by the fact that the elements of the structure only resist compressive or tensile stresses, but not bending stresses (unlike ordinary beams). This enables an optimum use of the structure, covering large surfaces at a lower cost than when using beams.

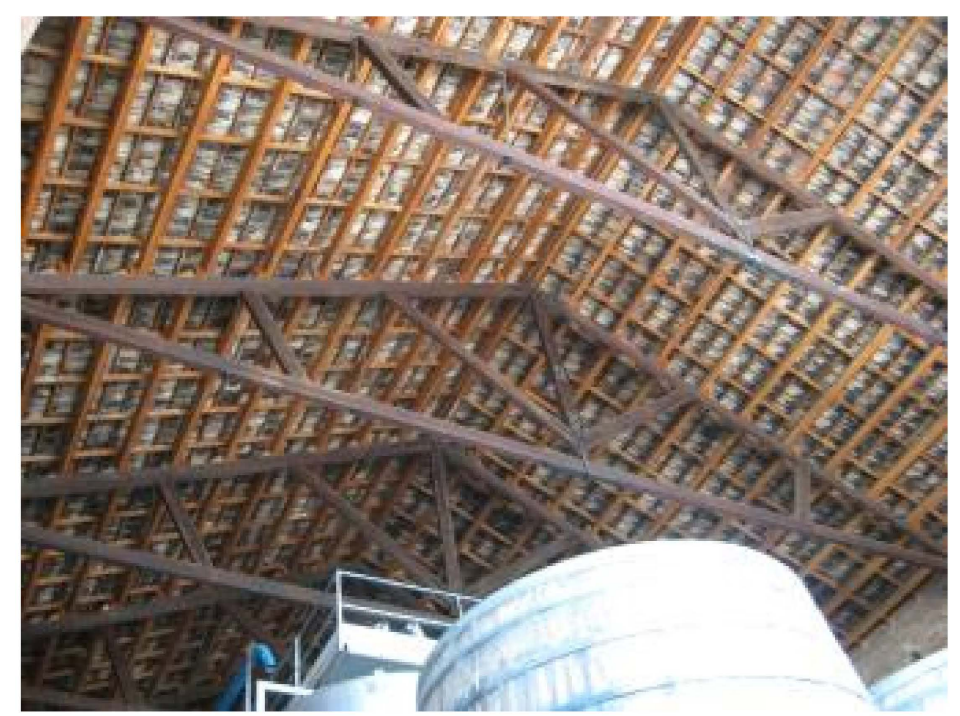

Figure 4. Wood roof trusses in the Falset cellar by Cèsar Martinell, 1919.

Other traces of both Medieval Gothic and Romanesque architecture, such as elongated windows (large windows were a key element for illuminating the interior space), voussoir arch doors, triforium openings, arcades, crenellated mouldings or pinnacles as decorative elements on the façades, are found in winery cooperatives.

Regarding the materials, bricks were the most characteristic and most used material in the construction of winery cooperatives. They were mostly chosen as an element of support and they are also the main constructive element in a lot of interior spaces (pillars, parabolic arches, voltes catalanes, etc.). Bricks were also used as ornamentation for façades and the bottom part of arches. They have an elegant presence on the outside of the buildings, especially at the main entrances. The most used constructive system on walls was brickwork, which were rendered with lime mortar on façades, or with cement inside the building. Mortar was economical and easy to use on façades; it was also necessary for binding bricks and other materials. Sometimes, the brickwork remained unrendered, especially the lower part of the walls, as a base meant to provide greater resistance to soil moisture.

Although wood is present in all the cellars, in a lot of cases it was replaced by bricks. At that time, wood usually came from Europe, still recovering from World War I, which caused the increase in the cost of this material. For example, the wood from Flanders became five times more expensive, whereas bricks were still very cheap.

Iron, for its part, despite being very important in a lot of Art Nouveau buildings, is hardly present in cellars, because it was expensive to work with. For this reason, it was used scarcely for decoration.

Finally, ceramics was also a very commonly used material in winery cooperatives. It was basically used for decoration, but it also had a constructive role (for example, in the volta catalana, together with bricks). With respect to the decorating aspects, glazed ceramics was one of the most used elements in the ornamental expression of wine cellars, both as functional elements (roof tiles, gutters) and decorative elements. The use of glazed ceramics corresponds to the phenomenon of recuperating artistic professions applied to architecture and urbanism, which was one of the aspects that contributed to the Noucentista ideal of public beauty. 
In summary, it could be said that the great virtue of winery builders was to know how to take advantage of all the architectural solutions they had at their disposal. From the Art Nouveau masters they took three basic reference elements: the use of parabolic arches (direct legacy of Gaudí); the profuse decoration of the façades; and the use of noble materials such as stone, bricks, terracotta and ceramics. In fact, Art Nouveau architects recovered and dignified these materials used for centuries by the masters in traditional architecture. This high regard given to the Catalan building tradition of all ages was one of the confluent points between Art Nouveau and Noucentisme. On the other hand, the distribution and use of space, the desire to create an efficient building integrated in the rural urban ensemble, as well as the location of the windows and the innovative use of modern flat brick vaults, were some of the Noucentista contributions.

\subsubsection{Cèsar Martinell: Humanist and Innovative Architect}

Cèsar Martinell was born in Valls in 1888, the year in which Barcelona was celebrating its Universal Exhibition. In 1906, he went to the capital in order to begin his university studies. At that moment, Art Noveau was present everywhere in the city and Noucentisme began to appear. At the School of Architecture of Barcelona, Martinell's teachers were renowned architects, such as Lluís Domènech i Muntaner and August Font i Carreras. He also went to Francesc Galí's well-known private drawing school. Towards the end of his university degree, he began to frequent some of the architects of Gaudís group, such as Josep F. Ràfols and Joan Rubió i Bellver. These influences were decisive for the creation of his own style, in which different tendencies can be found; the fact of knowing Antoni Gaudí personally in 1915, when he was entirely dedicated to his major work, the Sagrada Família, was a significant moment for the young architect, as may be observed in his agricultural architecture, in which he used the aforementioned parabolic arches, which are highly relevant in Gaudi's architecture [20,21].

Before setting about building his first cellar, Martinell had already built some single-family houses and apartments in Valls and in Santa Coloma d'Andorra. When he received his first commission for a cellar from an agricultural union, he wanted to improve some aspects with respect to the cellars that had already been constructed by other architects. Although he based his project on the cellar of l'Espluga de Francolí by Domènech i Roura (in terms of the floor plan and the monumental façade), he had a lot of conversations with the farmers before building it, in order to take into account certain aspects they were worried about and providing solutions. Some of these aspects were the use of cheaper materials; the need for openings on the floor for the exit of acids and for ceramic pipes for the air circulation and ventilation; the separation of the wine tanks; and, of course, his hallmark, the use of parabolic arches.

Cèsar Martinell was an intellectual transmission bridge in between the second generation of masters of the Catalan Renaixença (Antoni Gaudí, Lluís Domènech i Montaner, Josep Puig i Cadafalch, etc.) and the post-war generation. His industrial architecture received direct influence from Gaudí for his architectural constructive and space solutions and from Domènech his forms and materials. On the other hand, in his public and domestic architecture, he was more influenced by the new values of Noucentisme (classicism and simplicity) and other styles from his time, such as rationalism.

During his lifetime, he designed approximately 50 cellars and oil mills for different unions under the government of the Mancomunitat, using practical and economical parabolic arches made of bricks. The artist Xavier Nogués collaborated with Martinell making ceramic tile panels in many of his cellars. He also incorporated important technical innovations to obtain better product quality.

\section{Case Presentation: Restoration of the Wine Cellar Cooperative in Falset}

In 2009, the 'Departament de Cultura de la Generalitat de Catalunya' (Culture Department of the Generalitat de Catalunya) and the 'Obra Social La Caixa' signed an agreement in order to renovate eight cellar cooperatives of great artistic value, seven of which were built by Cèsar Martinell. The restoration of the cellar cooperative of Falset presented below was carried out within the framework of the aforementioned restoration and improvement of cellar cooperatives. CUBIC, the office of architects 
Ramon Valls and Isabel Pascual, which is the author of different buildings and works of restoration, was in charge of the restoration of this building.

All work carried out was aimed at emphasizing the architectural value of the building by applying the most convenient building solutions. It is important to highlight that the main objective of the restoration work performed was to recover the original appearance and spirit of the building, in accordance with the original plans of the architect Cèsar Martinell. This is particularly important given the fact that over the past few decades work had been carried out on the building on several occasions, but only the functional needs of the building were taken into account, leaving aside concepts such as the utilitarian value of beauty, harmony with nature, aesthetics, etc., all very important aspects in Cèsar Martinell's work.

\subsection{Architectural and Constructive Description of the Building}

The wine cellar cooperative in Falset was built in 1919 as a commission from the farmers' union of the village. Cèsar Martinell had received advice from Josep M. Valls, director of the 'Agriculture Technical Services' of the Mancomunitat de Catalunya, and from Erasme M. Imbert, a renowned engineer and oenologist.

The building consists of two rectangular blocks of different dimensions, located perpendicularly to each other and connected between two parabolic arches. This layout responds to the division of working spaces: the main building (the fermentation area) is divided into three naves, separated by exposed brick pilasters joined together by parabolic arches. The secondary building, for its part, consists of the wine-production nave and the area where the grapes are unloaded (Figure 5).

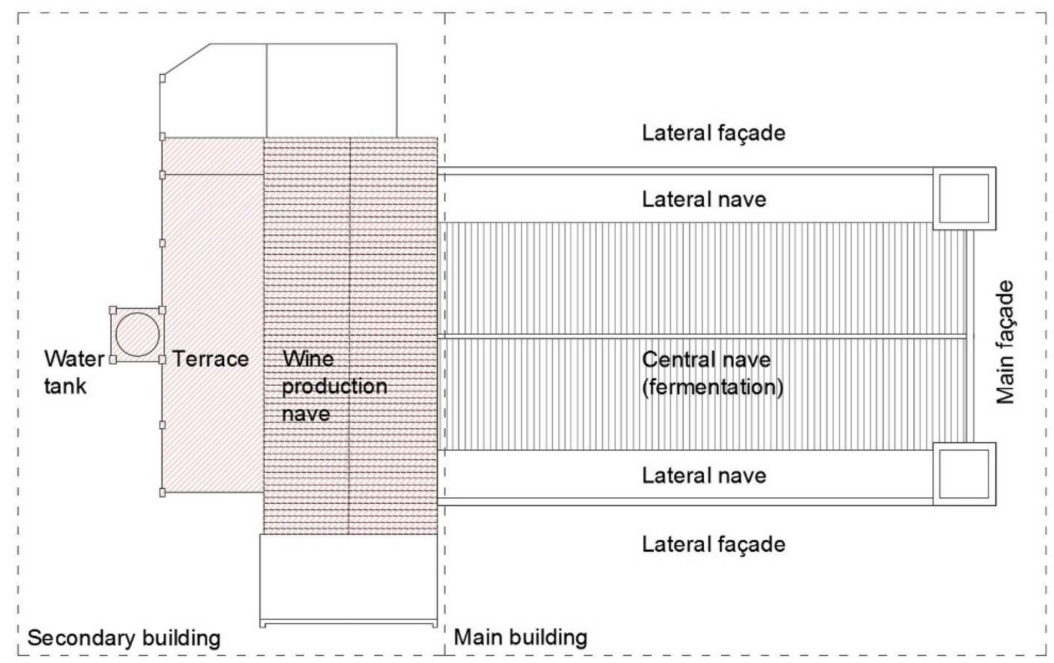

Figure 5. Floor of the wine cellar in Falset.

The fermentation containers, which were originally made of oak and now of stainless steel, are located in the three naves of the main building, occupying an area of $23.5 \mathrm{~m} \times 37.5 \mathrm{~m}$. There are still two original wooden containers used for making vermut, a dry wine for appetizers. The vats are arranged in two rows in the central area and one in each side area (Figure 6). They are elevated and supported by Catalan vaults, in order to separate them from the ground and use the space underneath for storing tools. Below this floor there are underground containers used for the second fermentation. 


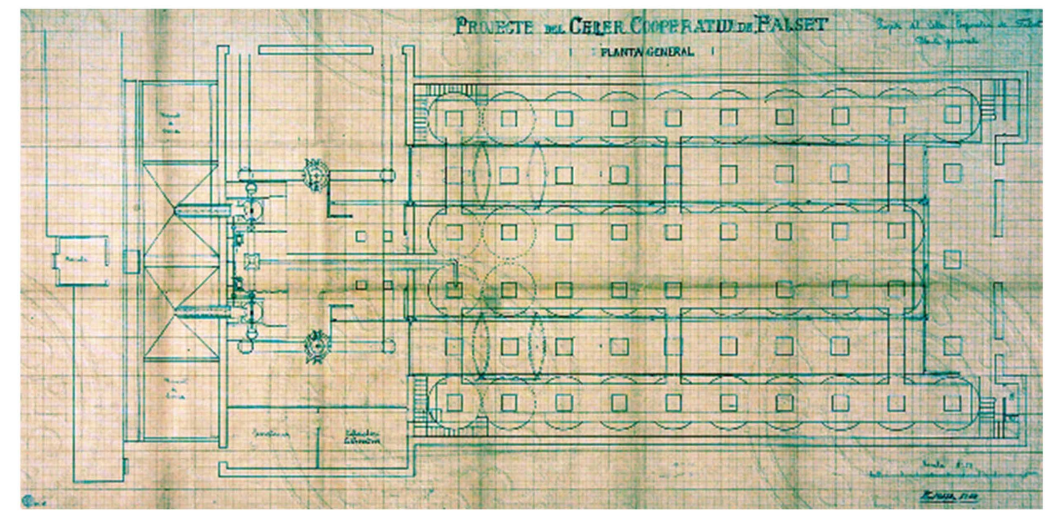

Figure 6. Cèsar Martinell, original floor plan of the wine cellar in Falset, 1919.

The roof covering structure of the main building consists of a 15-m-span wood roof truss that leans on brick pillars. The roof of the secondary building is also composed of a wood roof truss of approximately $12 \mathrm{~m}$. Roof tiles were used to clad the roofs; the roof made of French tiles ensures proper ventilation inside the building. Some of the tiles are made of green polychrome ceramics, creating a saw-shaped frieze on the two sides of the main roof. Glazed tiles emphasizing the eaves of the roof are also found on the main and side façades of the building. The absence of structural parabolic arches on the roof of the cellar supposes a big difference in Falset, because of the lack of these defining elements in Martinell's architecture. Parabolic arches, nevertheless, appear in other parts of the building, as doors or windows (Figure 7).

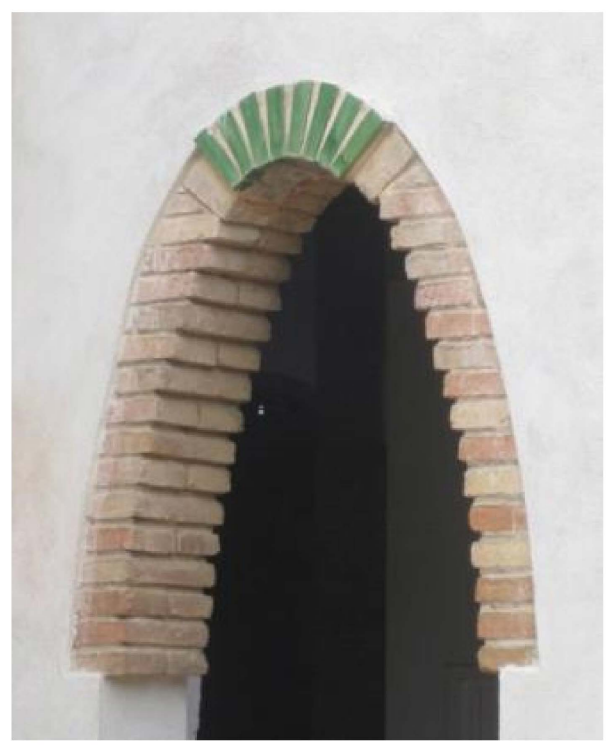

Figure 7. Parabolic arch on one of the doors.

The main façade of the building has two square plan towers at the extremes, with crenellated mouldings and brickwork in the corners, giving a medieval air to the construction (Figure 8). Cèsar Martinell took into account Falset's medieval tradition in the design of the façade of the wine cellar because, as he said, it was important to look at the past to build the present. In the center of this façade, a big granite midpoint arch is opened as the main entrance of the building (Figure 9). On top of this entrance, in the center of the façade, there are a group of nine narrow and elongated parabolic windows, framed with bricks. These windows are joined under a single discharging arch leaning on four pilasters. The motif of narrow parabolic windows is repeated in the secondary building. 


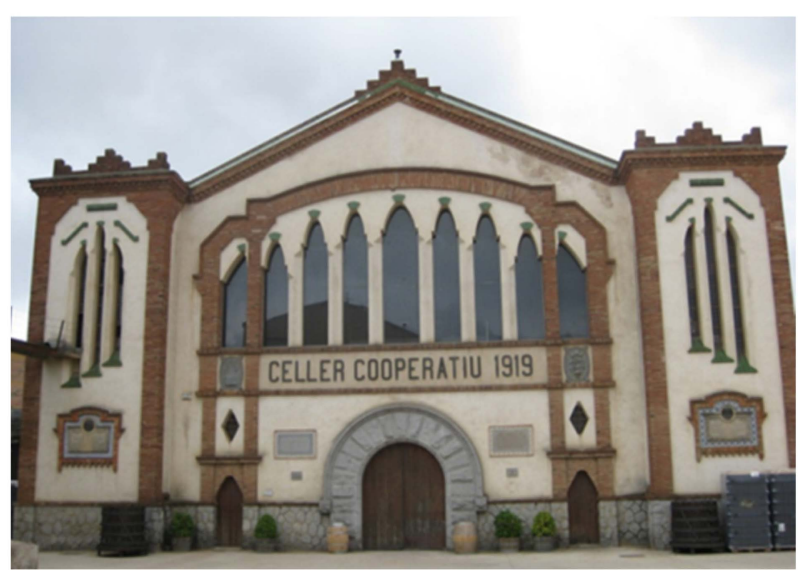

Figure 8. Main façade of the building.

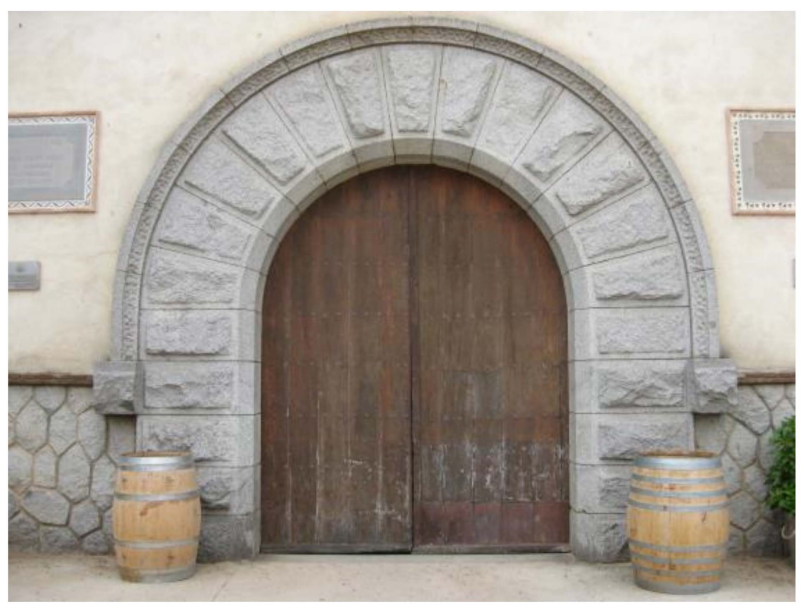

Figure 9. Medieval influence in the midpoint arch of the entrance.

In the middle of the main façade, there is a plaque with the name of the cellar (Celler Cooperatiu 1919), flanked by two shields. One of the shields shows the flag of Falset (a castle), while the other one is a symbolic drawing of a goblet surrounded by rays from which a vineyard is growing. All these elements on the main façade are framed with bricks as ornamentation.

With respect to the materials of the façade, the building consists of an exposed brickwork base, which carries out the function of a baseboard to protect from ground moisture, while the rest of the walls are masonry. The masonry is mainly rendered with lime mortar; the bricks are exposed around the most significant elements of the façade (windows, doors and corners).

Regarding the façade decoration, Cèsar Martinell used green glazed ceramics as an ornamental element on the four façades of the building, placing them in different positions. On the main façade, it is a key element on the arches constituting the central full-height windows, the windows in the towers and on the eaves of the roofs. On the side façades, green glazed ceramic tiles are present on the finish of the brick railing on the terrace, on the eaves of the roofs, on the sides of the towers and as the coating of several decorative spheres. On the back façade of the building, it is mainly found as decoration of the water tank of the wine cellar. This water tank, which was used to wash the machines, is situated on top of a small construction that used to house the scales used to weigh the grapes once they arrived and were unloaded at the wine cellar. Thanks to the elevated position of the water tank, it was possible to use water under pressure to wash the machines and small tanks using a hose.

The water tank is located on top of a structure supported by bricks arranged in the shape of two crossing parabolic arches. Its decoration consists of two green ceramic spheres at the bottom of the parabolic aches where the water tank is situated, and five more spheres finishing off the crown of the 
water tank. The water tank is no longer used but it is still one of the most characteristic elements of this wine cellar.

The flat roof of the secondary building, where the water tank is located, is also used for letting large bottles of wine oxidize under the sun for almost a year, in order to obtain the famous Catalan vi ranci (a sweet local wine normally taken for dessert with nuts or sweets).

\subsection{Initial Condition of the Cellar. Pathological Description and Basic Repair}

The use originally given to the construction is the main use the building still has today: a wine cellar. Because of this activity, the building had to be renovated so as to modernize its facilities and machines. Some of the obsolete interior elements were removed while some structural repairs, which prevented the wine cellar from functioning properly, also had to be performed.

Rehabilitation work related to the aesthetic and historic aspects of the building was also carried out. Improving the building in this sense enabled increasing and enhancing the alternative use given to the wine cellar a few years ago: organizing guided visits for tourists, some of them including theatrical performances, based on discovering the oenological heritage of the region, as well as on the history of agricultural cooperative movements in the area and the architectural aspects of this kind of industrial building.

The building was in good condition before its rehabilitation. All the structural elements were in good condition, with the exception of the roof structure of the secondary building, the wood roof truss of which was severely deformed and cracked. Those pathologies were caused by the general ageing of the material of the structure, affected by aggressive weather conditions (high temperatures and high levels of humidity generated by the wine-making process), by the attack of biological agents, and because of the lack of maintenance. The state of conservation of the building could be determined by visual inspection and simple prospecting methods which identified the most damaged parts.

On the roof cladding of the secondary building, some previous work had been carried out with the aim of renovating some structures. Fiber cement sheets instead of the original material (flat roof tiles) had been used for the cladding due to financial reasons. Fiber cement is a much cheaper option and it is faster to install but it is clearly unsightly in the building in question.

The roof of the main building was well preserved, so it was not necessary to perform any work on it.

The façades, in turn, were in an advanced state of deterioration. The main façade, which had been restored in the past, did not suffer any pathologies or visible deterioration, so it was excluded from the rehabilitation process. On the other façades, the main cause of the pathologies found was the lack of maintenance and the effects of atmospheric agents. Although they were not very serious, the pathologies caused a sensation of considerable neglect, especially at the back façade. Several walls had lost part of their rendering and, in the parts near the ground, there were areas where the bricks had come loose due to mechanical weathering and soil moisture. The bars on the windows were rusted and had stained the walls adjacent to the openings.

\subsubsection{Façades and Water Tank}

The main building pathologies of the exterior (façades and water tank) and their causes are shown in Table 1. 
Table 1. Damage in facades and water tank.

\begin{tabular}{|c|c|c|}
\hline Damage & Cause/Agent & Repair \\
\hline $\begin{array}{l}\text { Rusting of iron elements of the } \\
\text { façades and rust stains (Figure 10). }\end{array}$ & $\begin{array}{l}\text { Constant exposure to aggressive } \\
\text { atmospheric agents (mainly rain). }\end{array}$ & $\begin{array}{l}\text { Mechanical cleaning using a steel brush, } \\
\text { followed by manually applying an } \\
\text { anti-rust primer. }\end{array}$ \\
\hline $\begin{array}{l}\text { Loose render on the walls of the } \\
\text { façade (Figure 11). It also } \\
\text { supposed a risk to the safety of the } \\
\text { users of the building. }\end{array}$ & $\begin{array}{l}\text { Atmospheric agents (wind, rain, hail, } \\
\text { etc.), as well as thermal expansions } \\
\text { and contractions of the cladding } \\
\text { elements. }\end{array}$ & $\begin{array}{l}\text { Mechanical removal of the old render } \\
\text { using a hammer and replacing it with } \\
\text { sand-colored white cement mortar. }\end{array}$ \\
\hline $\begin{array}{l}\text { Deterioration of the decorative } \\
\text { glazed ceramics on the façades } \\
\text { and water tank. The decorative } \\
\text { spheres were particularly badly } \\
\text { damaged (Figure 12). }\end{array}$ & $\begin{array}{l}\text { Atmospheric agents and thermal } \\
\text { expansions and contractions of the } \\
\text { supporting elements of the ceramic } \\
\text { pieces, together with a lack of } \\
\text { maintenance. }\end{array}$ & $\begin{array}{l}\text { Mechanical removal of all old pieces } \\
\text { and replacing them with new ceramic } \\
\text { elements, using white cement mortar to } \\
\text { join the elements. }\end{array}$ \\
\hline $\begin{array}{l}\text { Deterioration of the base of the } \\
\text { walls of the façade (Figure 13). }\end{array}$ & $\begin{array}{l}\text { Erosion by atmospheric agents and } \\
\text { soil moisture. }\end{array}$ & $\begin{array}{l}\text { The affected areas were filled with } \\
\text { expansive mortar, and cladding was } \\
\text { applied uniformly on all the façades. }\end{array}$ \\
\hline $\begin{array}{l}\text { Addition of material that was not } \\
\text { original to the façade due to old } \\
\text { repair work carried out } \\
\text { (Figure 14). }\end{array}$ & Old repair works. & $\begin{array}{l}\text { Completely replacing the cladding of } \\
\text { the façade. }\end{array}$ \\
\hline $\begin{array}{l}\text { Dampness on the walls of the } \\
\text { façade: on some parts of the façade } \\
\text { (mainly around the drainage pipes } \\
\text { of the building) there were damp } \\
\text { stains (Figure 15). }\end{array}$ & $\begin{array}{l}\text { Incorrect installation when replacing } \\
\text { the original ceramic drainage pipes } \\
\text { and lack of a waterproof sheet on the } \\
\text { flat roof of the unloading nave. }\end{array}$ & $\begin{array}{l}\text { Removing the surface of the flat roof, } \\
\text { installing a waterproof sheet and paving } \\
\text { the surface again. }\end{array}$ \\
\hline $\begin{array}{l}\text { Cracks in the walls of the façade } \\
\text { and in the water tank: In some } \\
\text { parts of the building there were } \\
\text { cracks in the top part of the wall of } \\
\text { the façade, which went all along } \\
\text { the edge of the roof slab (Figure } 16 \\
\text { left) and in the walls of the wàter } \\
\text { tank (Figure } 16 \text { right). }\end{array}$ & $\begin{array}{l}\text { Expansion and contraction } \\
\text { movements originated by exposure to } \\
\text { atmospheric conditions. The cracks } \\
\text { had no movement. }\end{array}$ & $\begin{array}{l}\text { Removing the old render, manually } \\
\text { cleaning the joints with a steel brush, } \\
\text { and filling them again with a new } \\
\text { mortar, which is less stiff and more } \\
\text { resistant to the bending of cement and } \\
\text { glue, and finally coating the surface. }\end{array}$ \\
\hline
\end{tabular}

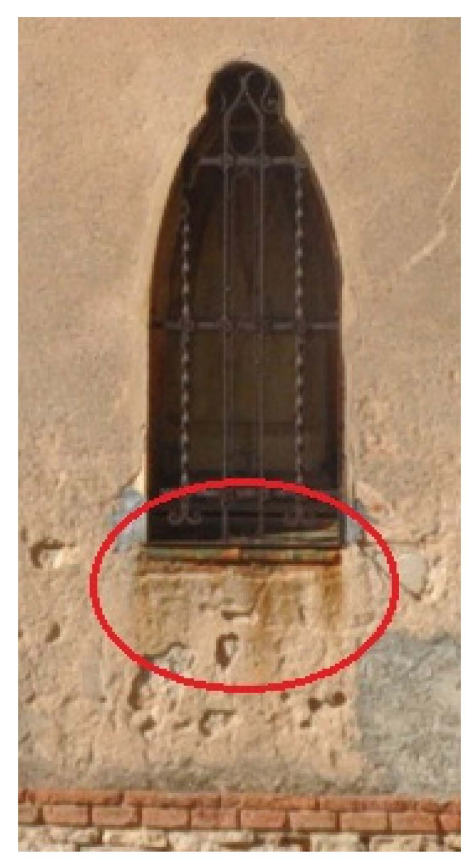

Figure 10. Rusting of the original bars of the windows. 




Figure 11. Loose render on the walls of the façade.
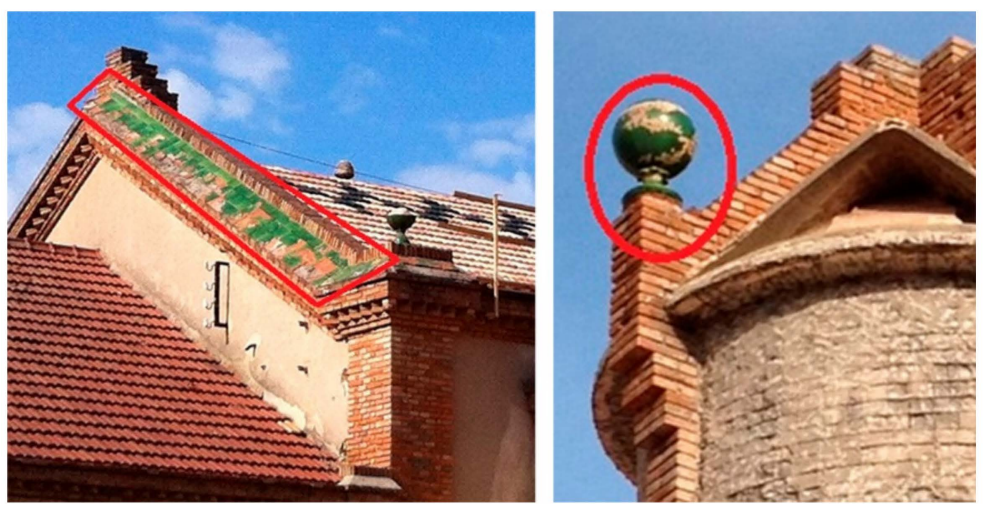

Figure 12. Deterioration of the decorative green ceramics on the roof and on the spheres of the water tank.

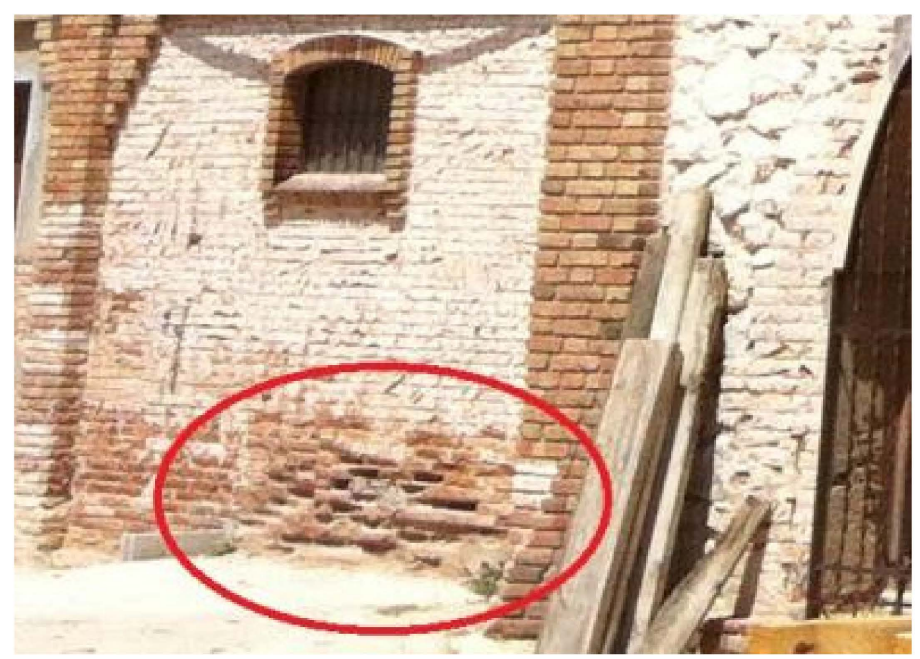

Figure 13. Deterioration of the base of the façade. 


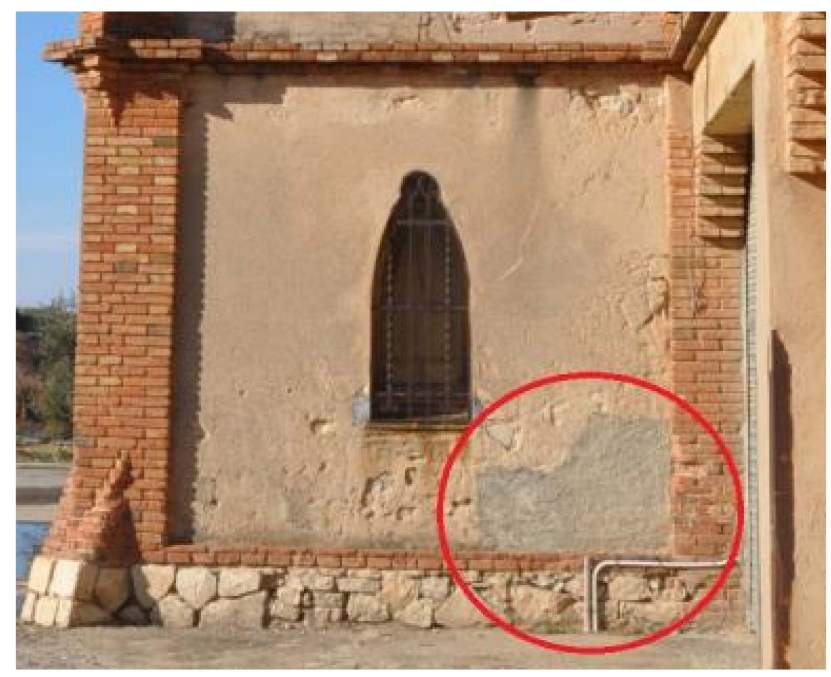

Figure 14. Addition of material that was not original to the façade.

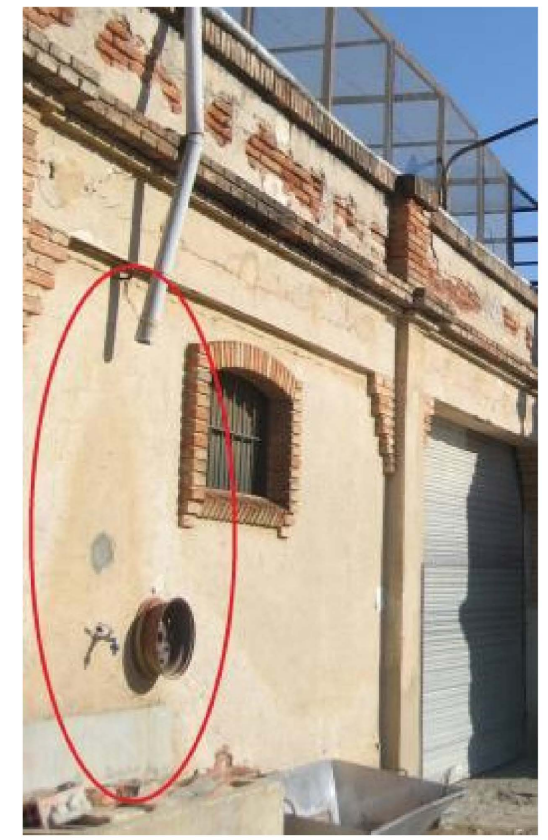

Figure 15. Dampness on the façade.
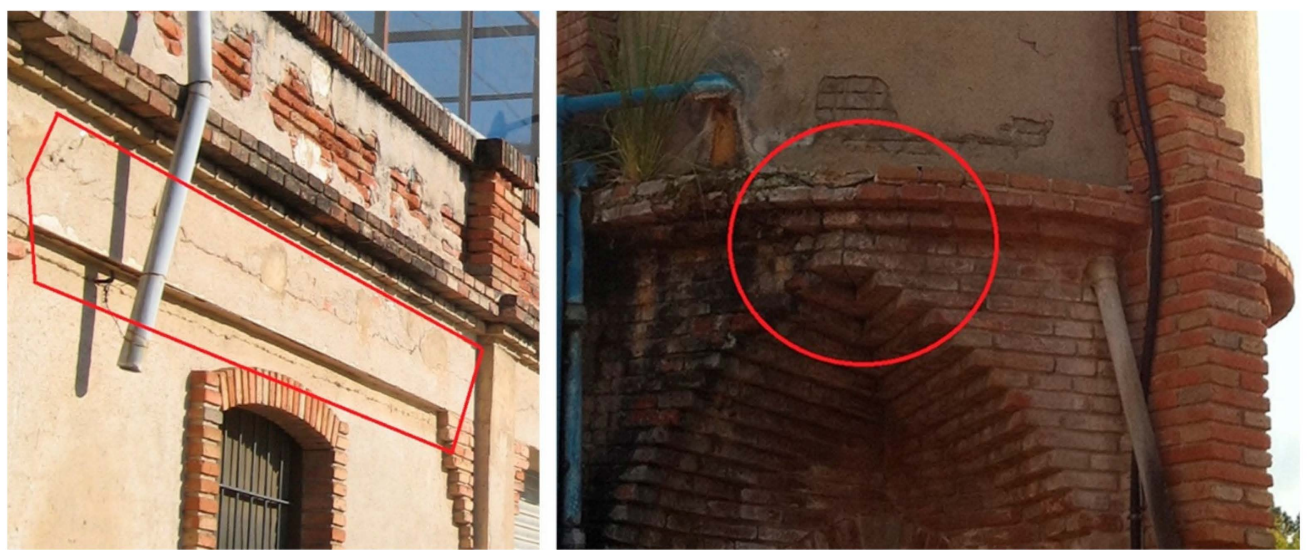

Figure 16. Cracks in the top part of the façade and in the water tank. 


\subsubsection{Pitched Roofs and Flat Roofs}

The main building pathologies on the pitched roofs and flat roofs of the building will be explained in Table 2.

Table 2. Damage in pitched roofs and flat roofs.

\begin{tabular}{lll}
\hline \multicolumn{1}{c}{ Damage } & \multicolumn{1}{c}{ Cause/Agent } & Repair \\
\hline $\begin{array}{l}\text { Rusting of the iron elements on the } \\
\text { flat roof of the unloading nave, } \\
\begin{array}{l}\text { which presented different levels of } \\
\text { rusting (Figure 17). }\end{array}\end{array}$ & $\begin{array}{l}\text { Exposure to aggressive } \\
\text { atmospheric agents and to a lack } \\
\text { of maintenance. }\end{array}$ & $\begin{array}{l}\text { Removal of iron elements and change of the } \\
\text { entire surface of the flat roof. }\end{array}$ \\
\hline $\begin{array}{l}\text { Dampness on the flat roof of the } \\
\text { unloading nave (Figure 18). }\end{array}$ & $\begin{array}{l}\text { the flat roof and the deterioration } \\
\text { of the waterproof sheet (due to } \\
\text { atmospheric agents and a lack of } \\
\text { proper maintenance) }\end{array}$ & $\begin{array}{l}\text { Removal of the surface of the flat roof, } \\
\text { installation of a waterproof sheet and } \\
\text { paving the surface again. }\end{array}$ \\
\hline
\end{tabular}

Erosion of the material on the roof of the unloading nave: Parts of the surface of the flat roof of the

Atmospheric agents and a lack of proper maintenance. unloading nave showed different levels of erosion (Figure 19).

Discordant paving materials on the flat roof of the unloading nave: Some parts on the flat roof of the unloading nave had different kinds of paving (Figure 20).

Previous repairs. Different paving materials behaved differently in front of atmospheric agents.
Removal of the surface of the flat roof, installation of a waterproof sheet and paving the surface again.
Dampness and loss of permeability on the roof of the wine-production nave: There were several broken fiber cement sheets on the roof, which could not guarantee the permeability of the nave (Figure 21)
Deterioration of the roof materials due to the effects of atmospheric agents and to a lack

of maintenance.
Removal of the surface of the flat roof, installation of a waterproof sheet and paving the surface again.

Dampness on the bearing wall of the structure on the roof of the wine-production nave: The gutters Atmospheric agents and a lack collecting rainwater on this roof of maintenance.

Entire replacement of the wine-production nave roof.

Entire replacement of the wine-production nave roof.

were in very poor condition (Figure 22).

Loss of load-bearing properties of the roof structure of the wine-production nave: the materials of the support structure on the roof of the wine-production nave (wood roof trusses) were greatly deteriorated, which affected the stability and structural properties of the roof (Figure 23). The wood showed a generalized loss of section of approximately $5 \%$.
Biotic pathologies caused by inects (cerambycidae, Anobium punctatum, Xestobium rufovillosum and Lyctus brunneus) and fungi.
Preventive and curative chemical treatment against wood-boring insects on all the parts of the roof trusses. The cracked beams could be recovered by applying epoxy repair resin in order to re-establish their load-bearing properties. Regarding serious cracks, split across the grain, or a substantial separation of the fractured parts, it was proposed to use high resistance glass fiber rods to join and consolidate the structural strength of the elements. The pathologies and structural deficiencies observed on the wood of the roof trusses were so numerous that it was financially more convenient to replace all the elements. 


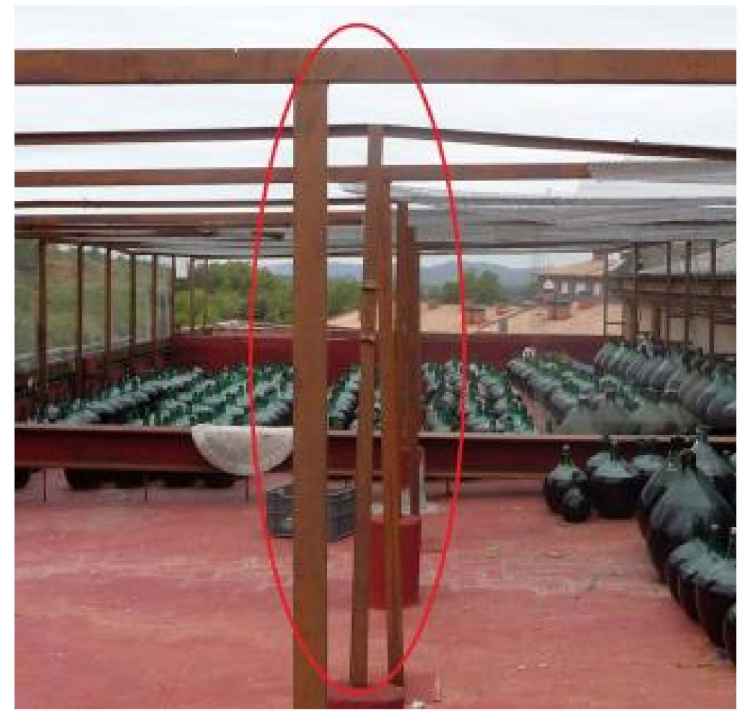

Figure 17. Rusting of metal structures on the flat roof.



Figure 18. Dampness on the surface of the flat roof.

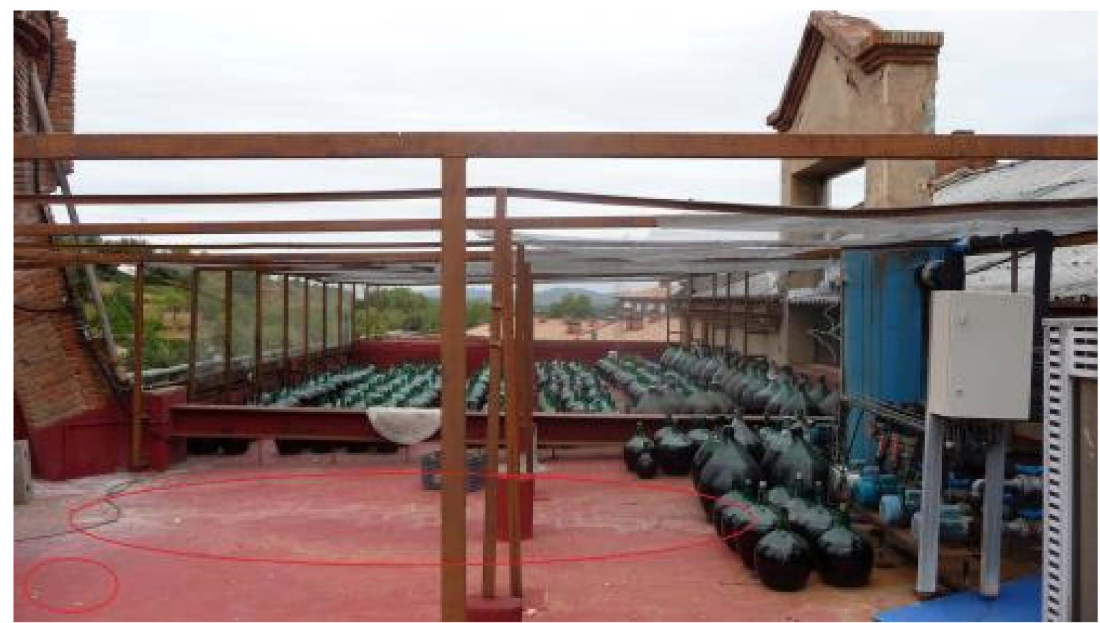

Figure 19. Deterioration of the surface of the flat roof. 


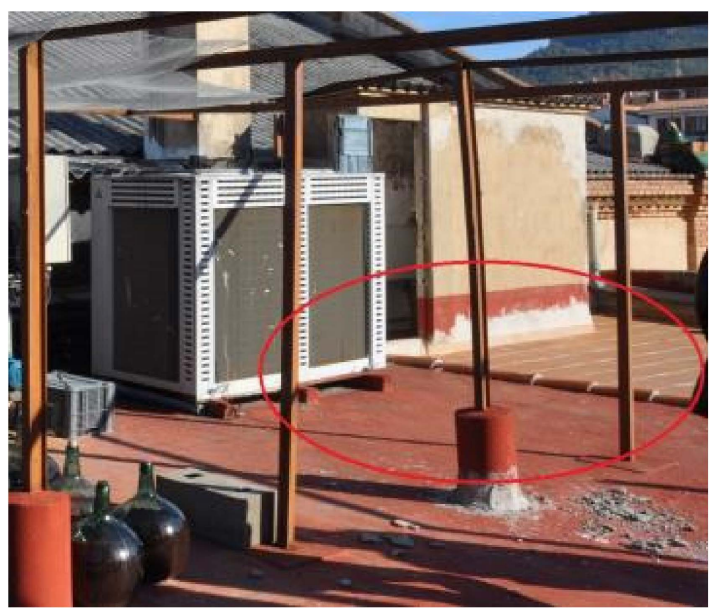

Figure 20. Discordant paving on the flat roof.



Figure 21. Condition of the roof of the wine-production nave (exterior) before restoration.

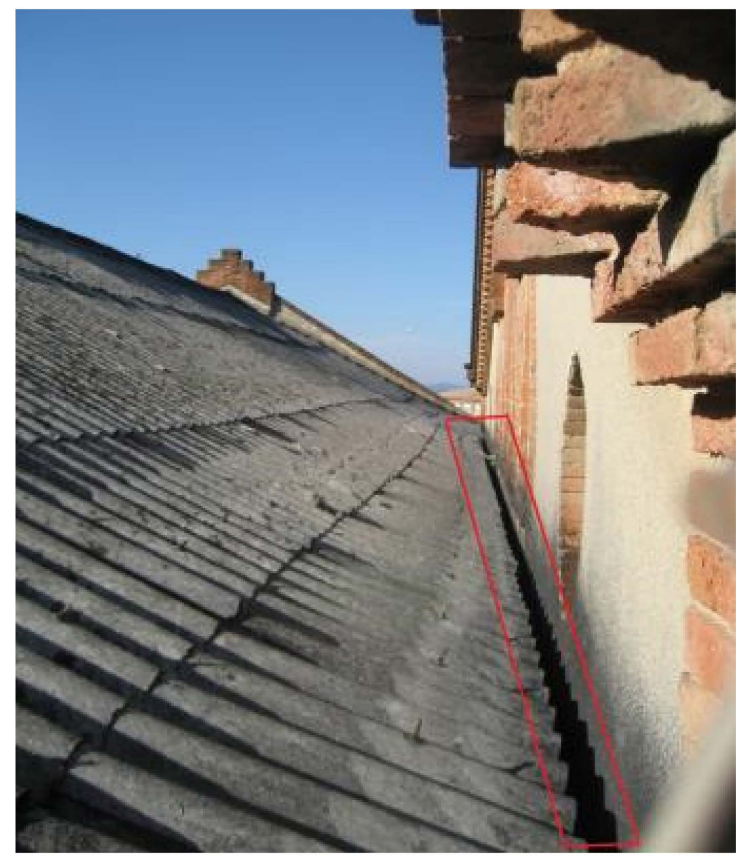

Figure 22. Dampness in the joint between the roof and the façade. 



Figure 23. Condition of the production nave roof (interior) before restoration.

\section{Discussion: Main Restoration Works Carried Out}

The main restoration works, in addition to the punctual and simple repairs of other elements mentioned above, revolved around the façade of the wine-production nave of the cellar, including the elevated water tank. The roof of the wine-production nave was also restored and an access to the flat roof of the unloading nave was built (Figure 24).

The building solution used on the roof allows natural ventilation of the wine cellar without losing its function of protecting from rain. It was essential to encourage recycling the air inside and getting rid of the steam produced by the winemaking process. The original dormer windows in the wine-production nave were also recovered, and the space was provided in this way with the necessary light to substantially reduce electricity costs. Furthermore, the location of the machines and the pipe runs of the water-cooling system were rationalized.
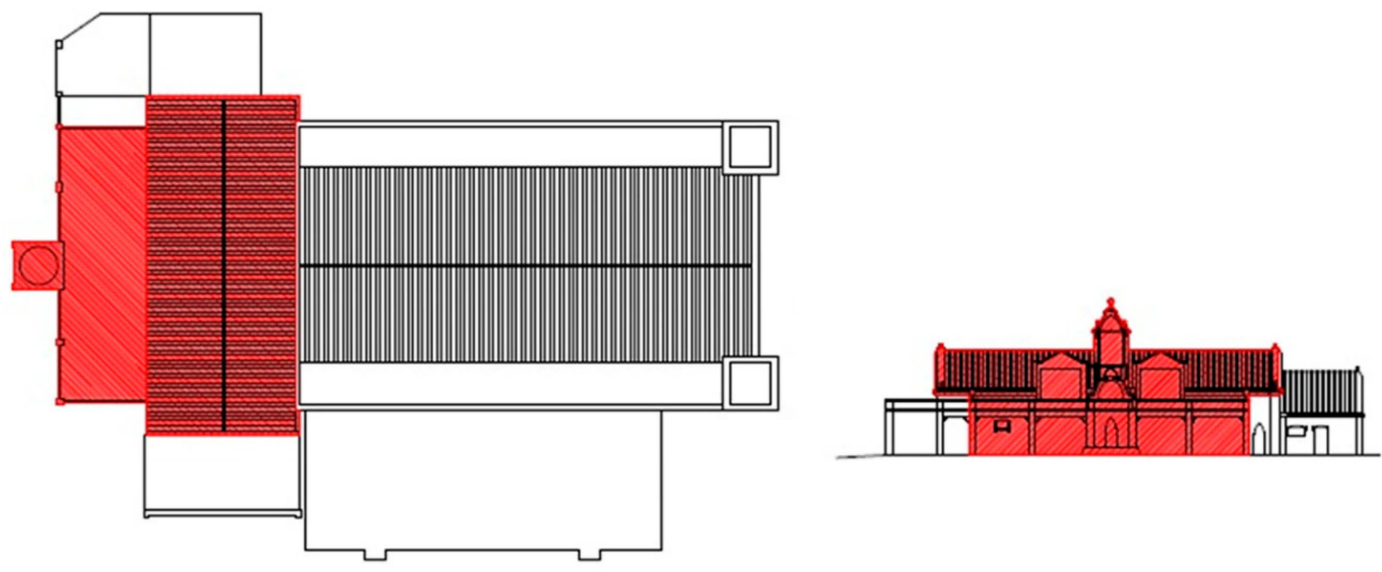

Figure 24. Restorations carried out.

The main characteristics of the building solutions of the affected elements are described in the following sections.

\subsection{Façades and Water Tank}

First of all, the cracks of the exposed brickwork were mended, substituting the deteriorated parts and repairing the mortar joints. The decorative elements and the finishes of the façade and the water tank were recovered (Figures 25 and 26). Finally, the lime mortar render was repaired and painted.

The reparation of the walls of the exterior façade consisted in the following actions: removal of loose render; cleaning of joints up to $2 \mathrm{~cm}$ of the exterior wall; applying a coat of levelling mortar to the exposed brickwork; applying a two-coat $(10+10 \mathrm{~mm})$ base mortar finish; applying two coats of aerated lime plaster; surface cleaning; and finally applying a PH neutralizer. 

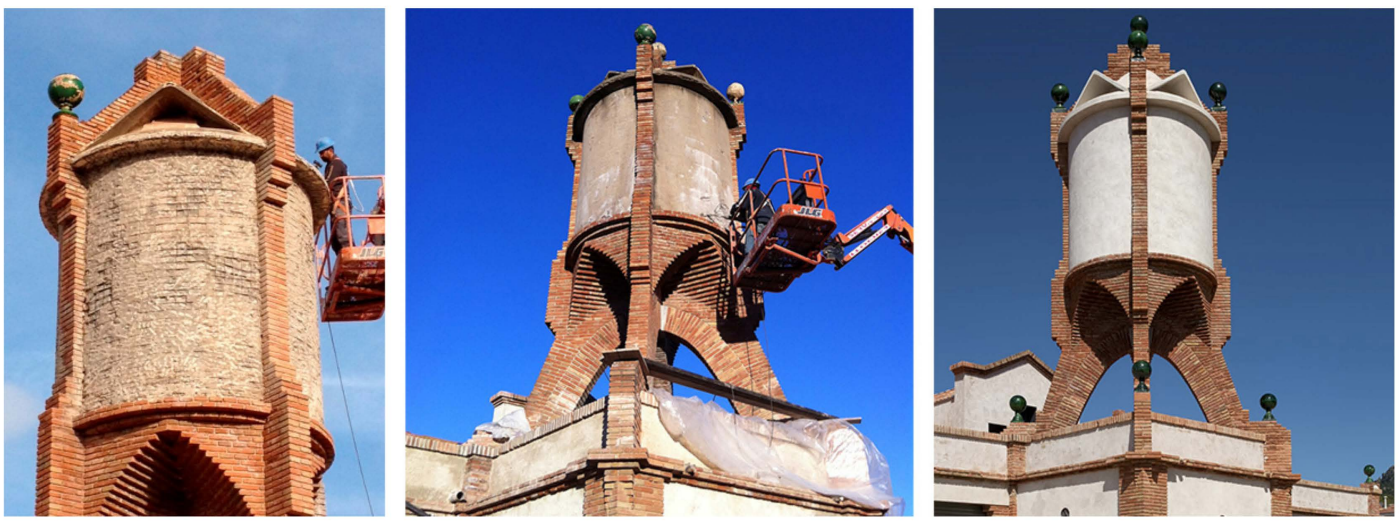

Figure 25. Water tank during restoration (left and center). Water tank after restoration (right).
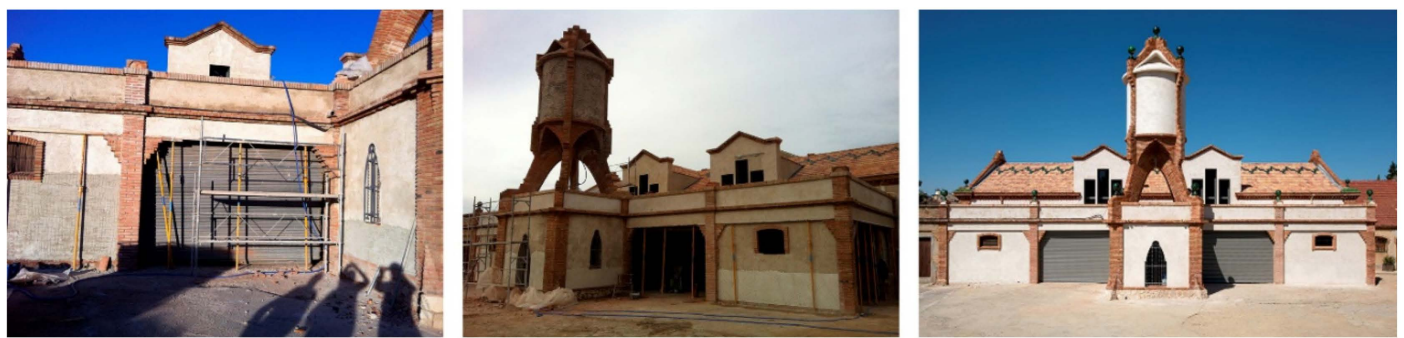

Figure 26. Back façade during restoration (left and center). Back façade after restoration (right).

\subsection{Pitched Roofs and Flat Roofs}

The original volumetric, building system and materials of the roof of the wine-production nave were recovered (Figure 27). The structure of the roof was rebuilt following the plans of the original roof, which consisted of a main structure comprised of laminated wooden roof trusses, a flanders pinewood sub-structure, tiling battens, joist brackets and complementary steel tensioners.


Figure 27. Roof structure of the wine-production nave during restoration (left). Roof structure of the wine-production nave after restoration (right).

The initial idea was to recover the original roof trusses, but they were so badly deteriorated that it was more economical to change the entire structure. The measuring of the new wood truss was carried out using a structure calculation program in three dimensions called Metal 3D, from the CYPE Company. A model of the structure of the roof is shown below (Figure 28) (all the roof trusses have the 
same dimensions and so have the dormer windows structures), as well as a table with the dimensions of the different bars (Table 3).



Figure 28. Diagram of the calculation of the wood structure of the roof.

Table 3. Dimensions of the bars of the wood roof structure.

\begin{tabular}{ccc}
\hline Bar Number & Section (Height $\times$ Width) & Material \\
\hline 1 & $300 \times 120 \mathrm{~mm}$ & GL24h (pine wood) \\
2 & $160 \times 120 \mathrm{~mm}$ & GL24h (pine wood) \\
3 & $120 \times 80 \mathrm{~mm}$ & GL24h (pine wood) \\
4 & $240 \times 120 \mathrm{~mm}$ & GL24h (pine wood) \\
5 & $\varnothing 16 \mathrm{~mm}$ & S275 (steel) \\
6 & $280 \times 240 \mathrm{~mm}$ & C22 (pine wood) \\
7 & $320 \times 220 \mathrm{~mm}$ & C24 (pine wood) \\
8 & $240 \times 120 \mathrm{~mm}$ & C24 (pine wood) \\
9 & $120 \times 80 \mathrm{~mm}$ & C24 (pine wood) \\
10 & $200 \times 100 \mathrm{~mm}$ & C24 (pine wood) \\
\hline
\end{tabular}

Recovering the original building materials meant substituting the fiber cement sheets of the roof for a finish using flat tiles from Alicante (Figure 29). The original design of the roof, which consisted in a frieze with green glazed tiles, was recovered.

When building the roof of the wine-production nave, it was observed that, originally, the dormer windows (which were glazed and lit part of the wine-production nave) were integrated into the roof volume. Furthermore, in order to access the flat roof of the unloading nave it was necessary to go through one of the dormer windows. Repairing the roof of the wine-production nave thus meant recovering those obsolete dormer windows as well as building a suspended staircase to connect the inside of the wine-production nave to the roof of the unloading nave. The existing staircase was removed, drawing the roof profile of the nave again, in the same way Cèsar Martinell had designed it.

By recovering and integrating the original dormer windows into the roof volume, the front part was built using wood carpentry and the sidewalls were brickwork walls rendered with lime mortar on the new roof trusses (Figure 30). A door was added to the dormer window facing east so as to have access to the roof from the inside of the wine-production nave. 



Figure 29. Roof of the wine-production-nave during restoration (exterior detail of tiles) (left). Roof of the wine-production nave roof after restoration (exterior detail of tiles) (right).
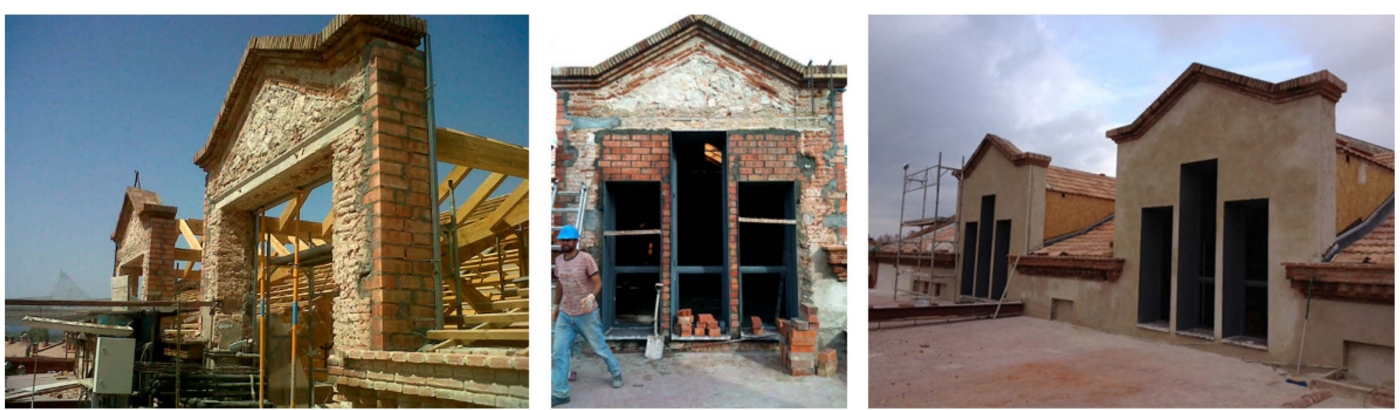

Figure 30. Dormer windows of the production nave during restoration (left and center). Dormer windows of the production nave after restoration (right).

Regarding the flat roof of the unloading nave, in order to solve all the pathologies it presented, it was decided to build a new roof for recovering its permeability and the uniformity of its entire structure. The building work performed on the roof of the unloading nave consisted in the removal of all metal posts, wires, antennae, fittings, etc., the demolition of obsolete structures and additions and realignment of the roof. After, the construction of a new roof surface was carried out with a waterproof butyl rubber membrane finished with flat clay tiles.

\subsection{Work Carried out Inside}

First of all, the silo in disuse in the wine-production nave was demolished. The adjacent staircase was also demolished and new stairs were built. After this, an access to the flat roof through the wine-production nave was made. This access consisted of a steel staircase suspended from the main structure of the roof of the production nave, and it was made through the new openings of the dormer windows, thus recovering the idea of Cèsar Martinell's project (Figure 31). 


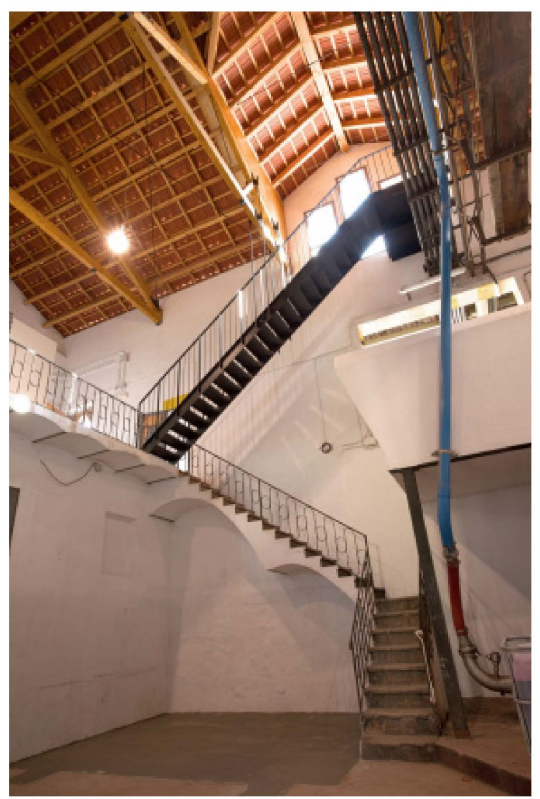

Figure 31. New staircase access to the restored roof of the unloading nave.

\section{Conclusions}

The recovery of industrial heritage oriented towards tourism is gradually becoming more important, both internationally and in Spain, as all kinds of industrial buildings are being recovered and rehabilitated. This kind of tourism does not only make a cultural product of major importance for the development of any country or region known; it also helps recover landscapes and degraded areas (because the industrial activity carried out in them has been abandoned). In Spain, the case of Catalonia is particularly interesting, as it is the region that best promotes the recovery of its industrial heritage.

On the other hand, one of the cultural and touristic activities that has grown the most over the last years has been oenological tourism. In Catalonia, this kind of tourism is mainly concentrated in the wine regions, the province of Tarragona being the one with the most designations of origin (D.O), and the region of Priorat being the only one with a Qualified Designation of Origin (DOQ). Oenological tourism is closely connected to the industrial products of the territory and their highest expression is to be found in the buildings typical of this kind of industry: cellars.

The importance of cooperative organizations in Catalonia is linked to the development of aforementioned wine cellars at the beginning of the 20th century, and, as a result, to the history of the cultural heritage of the country. Said heritage, which has often been pushed into the background of this category for being considered less important than other monuments and buildings, has the distinctive feature in this case of being built in an Art Nouveau style with certain Noucentista elements.

In the case of the wine cellar cooperative in Falset, built by Cèsar Martinell, an expert in this type of constructions at the time, it needs to be highlighted that it still carries out the same function as the one it was built for, something exceptional for this kind of constructions nowadays. Apart from that, a new use has been given to the building, currently offering visits to people interested in heritage and oenology.

The restoration of this cellar was aimed at highlighting the architectural value of the building by applying the most convenient building solutions. The main objective of the work performed was to recover the original appearance and spirit of the building, in accordance with the original plan of Cèsar Martinell. This is particularly important given the fact that over the past few decades work had been carried out on the building on several occasions, but only the functional needs of the building were taken into account, leaving aside concepts such as the utilitarian value of beauty, harmony with nature, aesthetics, etc., all very important aspects in the architect's work. 
Before describing the work carried out, the pathologies observed in the building were analyzed. Amongst the main causes of said pathologies were deterioration due to the building's industrial use, atmospheric agents and a lack of maintenance. By restoring the building, all those problems were solved. Restoring it furthermore enabled promoting and popularizing the current double use of the cellar in the Priorat region.

The work carried out was selected as a finalist of the 2013 Bonaplata awards, the objective of which is to recognize the value of and recover the industrial heritage of Catalonia, within the category of restoration of industrial heritage. This is a good example of how restoration policies (funding, awards ... ) are an excellent way of encouraging the care of industrial heritage and the consciousness of its importance. Restoring those buildings shows how they can benefit cultural tourism. In the case of the cellar in Falset, moreover, it can continue carrying out the original function it was built for: wine production.

Author Contributions: Conceptualization, E.C. and J.U.; methodology, E.C. and J.U.; investigation, E.C. and J.U.; resources, E.C., J.U. and C.C.; writing-original draft preparation, E.C. and J.U.; writing-review and editing, C.C.

Funding: This research received no external funding.

Acknowledgments: The authors want to acknowledge the support from: Isabel Pascual and Ramon Valls, architects (CUBIC); Carmela Torró and Núria Rello, architects and structure consultants; Xavier Domènech (Cooperativa Falset Marçà); Raquel Lacuesta; Alberto T. Estévez. The authors want to acknowledge the economic support from JG Ingenieros Consultores for the development of this study.

Conflicts of Interest: The authors declare no conflict of interest.

\section{References}

1. Mine, T.Z. Adaptive re-use of monuments "restoring religious buildings with different uses". J. Cult. Herit. 2013, 14, 14-19. [CrossRef]

2. Cho, M.; Shin, S. Conservation or economization? Industrial heritage conservation in Incheon, Korea. Habitat Int. 2014, 41, 69-76. [CrossRef]

3. The Nizhny Tagil Charter for the Industrial Heritage. In Proceedings of the International Committee for the Conservation of the Industrial Heritage (TICCIH), Moscow, Russia, 17 July 2003.

4. Álvarez, M.A. Patrimonio Industrial, Paisaje y Desarrollo Territorial. Revista Internacional de Ciencias Sociales 2010, 29, 21-29.

5. Casanelles, E. 75 Elements del Patrimoni Industrial de Catalunya. Barcelona; Museu de la Ciència i Tècnica de Catalunya: Terrassa, Spain, 1994.

6. Claver, J.; Sebastián, M.A. Basis for the classification and study of immovable properties of the Spanish industrial heritage. In The Manufacturing Engineering Society International Conference; MESIC: Zaragoza, Spain, 2013.

7. Rojas, J.I.; Castro, M.; Carranza, M.P. Contribution of the Spanish Historical Inventions to the Knowledge of Olive Oil Industrial Heritage. J. Cult. Herit. 2012, 13, 285-292. [CrossRef]

8. Lucchi, E. Simplified assessment method for environmental and energy quality in museum buildings. Energy Build. 2016, 117, 216-229. [CrossRef]

9. Lucchi, E. Review of preventive conservation in museum buildings. J. Cult. Herit. 2018, 29, 180-193. [CrossRef]

10. Stratton, M. Reviving industrial buildings. In Industrial Buildings: Conservation and Regeneration; Stratton, M., Ed.; E \& FN Spon: New York, NY, USA, 2000; pp. 8-29.

11. Cercleux, A.-L.; Merciu, F.-C.; Merciu, G.-L. Models of technical and industrial heritage re-use in Romania. Procedia Environ. Sci. 2012, 14, 216-225. [CrossRef]

12. Kang, D.J. An analysis of resource system for industrial heritage based on industrial typology. Land Plan. 2009, 44, 173-191.

13. Edwards, J.A.; Llurdés, J.C. Mines and Quarries: Industrial Heritage Tourism. Ann. Tour. Res. 1996, 23, 341-363. [CrossRef]

14. Xie, P.F. Developing industrial heritage tourism: A case study of the proposed jeep museum in Toledo, Ohio. Tour. Manag. 2006, 27, 1321-1330. [CrossRef] 
15. Rodríguez-Gonzálvez, P.; Muñoz-Nieto, Á.; Gozalo-Sanz, I.; Mancera-Taboada, J.; González-Aguilera, D.; Carrasco-Morillo, P. Geomatics and Geophysics Synergies to Evaluate Underground Wine Cellars. Int. J. Archit. Herit. Conserv. Anal. Restor. 2014, 8, 537-555. [CrossRef]

16. Planas, J. Cooperativisme i associacionisme agraris a Catalunya: Els propietaris rurals i l'organització dels interessos agraris al primer terç del segle XX. Ph.D. Thesis, Universitat Autònoma de Barcelona, Barcelona, Spain, 2003.

17. Mayayo, A. La Conca de Barberà 1890-1936: De la Crisi Agrària a la Guerra Civil; Centre d'Estudis de la Conca de Barberà: Montblanc, Spain, 1986.

18. Fuguet, J. El Celler del Sindicat Agrícola de Rocafort de Queralt (Conca de Barberà): Primera Obra Agrària de L'arquitecte Cèsar Martinell, 1918; Aplec De Treballs: Tarragona, Spain, 1987.

19. Martinell, C. Gaudí: Su Vida, Su Teoría, Su Obra; Colegio Oficial de Arquitectos de Cataluña y Baleares: Barcelona, Spain, 1967.

20. Lacuesta, R. César Martinell i Brunet, Arquitecto, Teórico e Historiador del Arte. Ph.D. Thesis, Universitat de Barcelona, Barcelona, Spain, 1974.

21. Lacuesta, R. Cèsar Martinell. Col-lecció del Centre de Documentació COAC, 7; Col·legi d'Arquitectes de Catalunya: Barcelona, Spain, 1998.

(C) 2019 by the authors. Licensee MDPI, Basel, Switzerland. This article is an open access article distributed under the terms and conditions of the Creative Commons Attribution (CC BY) license (http://creativecommons.org/licenses/by/4.0/). 